\title{
Value Relevance of available-for-sale financial instruments (AFS) and revaluation surplus of PPE (REV) components of other comprehensive income
}

\author{
Maryam Yousefi Nejad ${ }^{1, *}$, Azlina Ahmad ${ }^{2}$ \\ ${ }^{1}$ FEP Faculty economics and managements, Universiti Kebangsaan Malaysia \\ ${ }^{2}$ FEP Faculty economics and managements, Universiti Kebangsaan Malaysia
}

\begin{abstract}
Value relevance studies have thus far provided mixed evidence. Studies also found that fair value reporting has a significant impact on the value relevance of other comprehensive income. Additionally, most studies on value relevance of other comprehensive income focused on developed countries where the capital market is more efficient. In these settings due to the existence of active market, fair valuation of assets may not pose a major problem. In Malaysia the mandatory reporting of comprehensive income by all listed firms based on the requirement of FRS101, coincides with the adoption of FRS139 the standard for financial instrument and could be an interesting setting to investigate. This study hypothesized that other comprehensive income and its components are associated with share price. The results indicate that other comprehensive income and its components are value relevant. The results indicate that the move towards a more comprehensive income reporting through the preparation of the Statement of Comprehensive Income results in more informative financial reporting.
\end{abstract}

\section{Introduction}

One of important concept related to other comprehensive income reporting is the concept of fair value (e.g. [1][2]. Fair values of assets and liabilities change according to the changes in market value [3]. These changes give rise to the unrealized gains and losses which should be report in other comprehensive income. In great majority of countries, the market are less efficient to provide the necessary and reliable data for fair value measurement. Firms in these countries would have to use price of similar assets and liabilities or use projection of future benefits, and combine it in a model with all reasonable assumptions that are available in the market [3]; [4]. This situation may result in estimated values that are less reliable and may not truly be comparable between firms and countries [3]; [4].

In developed countries, market for most assets exist and pose no problem of reliability on the fair value measurement. However, in developing countries, some assets do not have available market, therefore, pose problem with fair value measurement, hence,

*Corresponding author: maryam_youssefinejad@yahoo.com 
reliability is questioned. Most studies on value relevance of comprehensive income, however are done in developed countries such as the USA [5] and Europe [6], where the market is efficient and fair valuation of assets is reliable. However, very little studies [7] have been carried out in developing countries, which provide a different setting due to differences in economic environments, rules and regulation as well as accounting standards. For example, in Malaysia as a developing country, majority of firms are family firm, and very conservatives compare to other developing countries. Thus, can findings of past studies be generalized to countries where market efficiency is far less than advanced countries and using of fair value may not be well accepted by investors due to the unreliability of the information for valuing assets?

In Malaysia the preparation of statement of comprehensive income was made mandatory beginning 1st January, 2010 under FRS 1011. The statement required public listed companies to separately report comprehensive income in their financial statements [8]. Adoption of FRS 101 which coincide with FRS 139 in Malaysia, provide a good opportunity to empirically investigate whether the other comprehensive income and its components are value relevant. Among components of other comprehensive income this study examines the value relevance of unrealized changes on available-for-sale financial instruments (AFS) and revaluation surplus of Property, Plant and Equipment (REV). The AFS and REV are components of other comprehensive income that are affected by fair value measurement. Moreover, AFS is influenced by FRS 139 coincides with the mandatory adoption of FRS 101 in 2010 and REV is influenced by FRS 116 in 2006.

This study contributes to the literature by providing empirical evidence on the value relevance of other comprehensive income. Despite many studies on value relevance of comprehensive income, there are limited empirical evidence on value relevance of other comprehensive income and its components after mandatory reporting of other comprehensive income in 2010. This study also contributes to the literature in a way that examines value relevance of other comprehensive income in a different market setting. Moreover, this study provides the empirical evidence on value relevance of two components of other comprehensive income which are affected from asset market, namely unrealized changes on available-for-sale financial instruments (AFS) and revaluation surplus of PPE (REV). The findings would help to better understand the value implications of components of other comprehensive income. This study provides empirical evidence on value relevance of other comprehensive income in a developing country. The result could be useful for policy maker in developing countries that have not mandatory reporting of comprehensive income and contemplating to do so. Additionally, this study addresses the concept of value relevance which is of interest to standard setters and policy makers of countries with developing economics that try to grab attention of investors to make more investment, and accordingly, accelerate economic growth.

\section{Literature review}

An assessment of the literature shows that the value relevance of comprehensive income, other comprehensive income and its components varies across countries and industries, and has also changed over time. In other words the results conducted so far by studies show the mixed results. Therefore, it is relatively difficult to compare the results of the past available studies in different countries. There are several possible explanations why these studies could not provide consistent results and further research is required to fill those gaps.

First, the IASB introduced the mandatory adoption of IFRS for listed companies with financial years starting on or after January 1, 2005. Moreover, the revision of IAS 1 and reporting of other comprehensive income components is only mandatorily applied for 
financial years starting on or after January 1, 2010. Therefore, comparable accounting data for doing empirical research has only been available since 2011. Due to this limitation, as a result, there are limited studies which their data are collected after effective date of IAS 1. The results obtained from the period after mandatory of comprehensive income reporting may lead to find results which they are more appropriate for assessing whether the capital market better understands the value implications of components of other comprehensive income.

Secondly, some of the prior studies suffered from potential measurement error. They had to calculate the other comprehensive income amounts (as-if data) due to unavailability of data instead of using actually reported values (as-reported data). For example [9],[10], [11], [12], [13] and [14] in their analysis used as if data. Despite of them for example [2] [15] and [6] use actual data of comprehensive income and other comprehensive income, however findings of them on value relevance of comprehensive income, other comprehensive income and its components, show mixed results.

Third, one of the reasons for the mixed result in the studies of value relevance of other comprehensive income, could be acceptance of IFRS, and its consequence, fair value. Early, the FASB required firms to report comprehensive income as the sum of net income and other comprehensive income. This requirement raises debates about the value relevance of other comprehensive income components as most important part of comprehensive income (e.g., [16] [5][10][17]. Then, the reporting of other comprehensive income is getting more attention because of the convergence of U.S. Generally Accepted Accounting Principles (GAAP) to International Financial Reporting Standards (IFRS) [18]. After introduction and adoption of IFRS and fair value accounting comprehensive income, and specifically other comprehensive income, become increasingly important for either practitioners or researchers [1]. This is because unrealized gains and losses in fair value of assets and liabilities are disclosed in other comprehensive income. The information provided by fair value could provide financial statement users with more complete, relevant, and representationally faithful information that should result in an improved basis for decision making [19].

Additionally, most studies carried up in developed countries where there are active market and obtaining a reliable measure for fair value is not a problem. However, there are very few studies on developing countries. One major issue is because in countries with developing economy asset market are less efficient to provide necessary and reliable data for fair value measurement. Firms in these countries would have to use price of similar assets and liabilities. This situation may result in estimated values that are less reliable.

Therefore, with respect to above, there is need to investigate value relevance of other comprehensive income with actual components of other comprehensive income instead of calculated data. Examining the value relevance of other comprehensive income also seems necessary after mandatory of other comprehensive income. Additionally the value relevance of other comprehensive income should be tested between different market efficiency and between different environments after convergence of IFRS.

\section{Hypotheses development}

This study identifies Efficient Market Hypothesis (EMH) as the relevant underlying theory. As discussed above, an information is said to be value relevant if it affect investors' decision and is reflected in the share price. This is in line with the efficient market hypothesis which states that an efficient market is a market in which its share prices always fully reflect all available information. The reporting of other comprehensive income and its components is aimed at enhancing financial reporting transparency. Therefore in line with the Efficient Market Hypothesis, other comprehensive income and 
its components information would have an effect on share price as such information could positively affect the ability of investors to make more effective decisions.

Therefore, based on the objectives of this study and the assertion of semi-strong form market efficiency this study hypothesize that:

H1: Other comprehensive income is positively associated with share price.

H1a: The unrealized changes on available-for-sale financial instruments component of other comprehensive income is positively associated with share price.

H1b: The revaluation surplus of Property, Plant and Equipment component of other comprehensive income is positively associated with share price.

\section{Methodology}

This study takes a quantitative approach and applies panel data design. The research samples were obtained from firms listed on the Main Market of Bursa Malaysia from 2011 to 2013. Data for this research was obtained from the Thomson Reuters DataStream Professional (DataStream) and Annual Reports of companies from 2011 to 2013.

In order to statistically examine the hypotheses, this study applies Ohlson's valuation model. In Ohlson's model, book value of equity and earnings are the explanatory variables of a firm's share price as follows:

$$
P_{\text {it }}=\alpha_{0}+\alpha_{1} B V E_{i t}+\alpha_{2} N I_{i t}+\alpha_{3} v_{t}
$$

Where:

$\begin{array}{ll}P_{\text {it }}= & \text { Share price } \\ B V E_{\text {it }}= & \text { Book value of equity per share } \\ N I_{\text {it }}= & \text { Net income per share } \\ v_{t}= & \text { error term }\end{array}$

This study develops the Ohlson's model and specifies Model 1 for testing first hypothesis $\left(\mathrm{H}_{1}, \mathrm{H}_{1 \mathrm{a}}\right.$ and $\left.\mathrm{H}_{1 \mathrm{~b}}\right)$ that investigates whether total other comprehensive income and its components are value relevant. The Model 1,2 and 3 are expressed as follows:

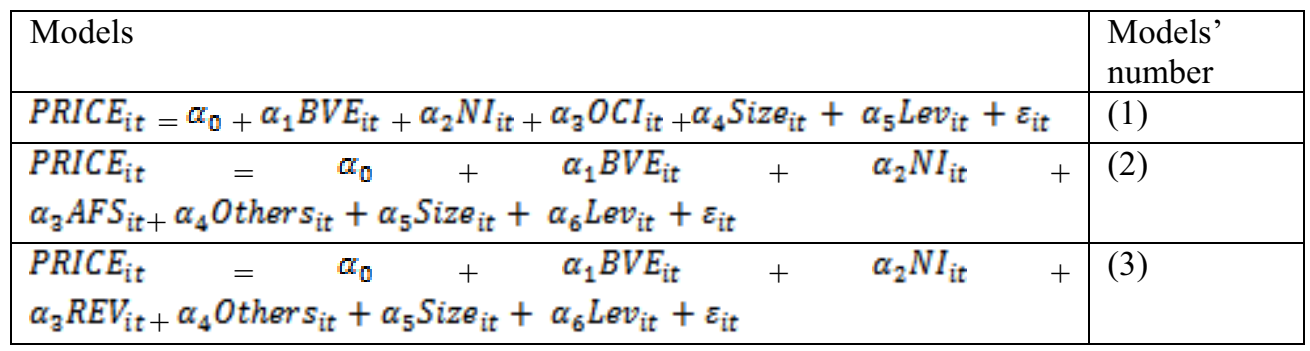




\section{Findings}

The regression analyses result of the first hypothesis (H1) reveals that total other comprehensive income is positively associated with share price. This means that total other comprehensive income is value relevant. The regression results of testing hypotheses $\mathrm{H} 1 \mathrm{a}$ and $\mathrm{H} 1 \mathrm{~b}$ indicate that the unrealized changes in available for sale financial instruments (AFS) and revaluation surplus of property, plant and equipment (REV) are significantly and positively associated with share price. In other words, unrealized changes in available for sale financial instruments (AFS) and revaluation surplus of property, plant and equipment (REV), are value relevant. In general it can be concluded that information on other comprehensive income and its component is informative and useful for investors' decision making.

\section{References}

[1] M. Bertoni and B. De Rosa, "COMPREHENSIVE INCOME , FAIR VALUE , AND CONSERVATISM : A CONCEPTUAL FRAMEWORK FOR,” pp. 1-14, 2013.

[2] K. Kanagaretnam, R. Mathieu, and M. Shehata, "Usefulness of comprehensive income reporting in Canada,” J. Account. Public Policy, vol. 28, no. 4, pp. 349-365, Jul. 2009.

[3] R. Ball, “( IFRS ): pros and cons for investors International Financial Reporting Standards ( IFRS ): pros and cons for investors," no. June 2013, pp. 37-41, 2006.

[4] M. Hoogendoorn, "International Accounting Regulation and IFRS Implementation in Europe and Beyond - Experiences with Eirst- time Adoption in Europe," vol. 3, 2006.

[5] D. Chambers, T. J. Linsmeier, C. Shakespeare, and T. Sougiannis, "An evaluation of SFAS No. 130 comprehensive income disclosures,” Rev. Account. Stud., vol. 12, no. 4, pp. 557-593, May 2007.

[6] A. Mechelli and R. Cimini, "Is Comprehensive Income Value Relevant and Does Location Matter? A European Study," Account. Eur., 2014.

[7] Q. Huang, J. Ye, and G. Du, "Value Relevance of Comprehensive Income in Small and Medium-size Enterprises," 2014.

[8] A. Abdul Rahman and M. D. H. Hmadan, "Reporting Comprehensive Income: Evidence from Malaysian ACE Market Companies," SSRN Electron. J., pp. 1-26, 2012.

[9] C. S. A. Cheng, J. K. Cheung, and V. Gopalakrishnan, "On the usefulness of operating income, net income and comprehensive income in explaining security returns," Account. Bus. Res., 1993.

[10] D. Dhaliwal, K. R. Subramanyam, and R. Trezevant, "Is comprehensive income superior to net income as a measure of firm performance?,” J. Account. Econ., vol. 26, no. 1-3, pp. 43-67, Jan. 1999.

[11] M. Brimble and A. Hodgson, "The Value Relevance of Comprehensive Income and Components for Industrial Firms,” Work. Pap. Griffith Univ. Bus. Sch. (Universiteit Amsterdam), 2004.

[12] J. Ernstberger, "The value relevance of comprehensive income under IFRS and US GAAP: empirical evidence from Germany.," Int. J. Accounting, Audit. Perform. Eval., vol. 5, no. 1, 2008.

[13] I. Goncharov and A. Hodgson, "Measuring and Reporting Income in Europe," J. Int. Account. Res., vol. 10, no. 1, pp. 27-59, Jan. 2011.

[14] H. S. Deol and J. A. Nazari, "The Decision Usefulness of Comprehensive Income Reporting: Evidence from Canada," 2013.

[15] H. Zülch and P. Pronobis, "The Predictive Power of Comprehensive Income and Its Individual Components under IFRS” no. 95, 2010.

[16] G. C. Biddle and J.-H. Choi, "Is Comprehensive Income Useful?,” J. Contemp. Account. Econ., vol. 2, no. 1, pp. 1-32, Jun. 2006. 
[17] D. a. Jones and K. J. Smith, "Comparing the Value Relevance, Predictive Value, and Persistence of Other Comprehensive Income and Special Items," Account. Rev., vol. 86, no. 6, pp. 2047-2073, Nov. 2011.

[18] C. Lee and M. S. Park, "Subjectivity in fair-value estimates, audit quality, and informativeness of other comprehensive income," Adv. Account., Jun. 2013.

[19] J. P. Jones and S. D. Stanwick, "Fair value accounting: A guide to understanding the current standards," J. Corp. Account. Financ., vol. 11, no. 1, pp. 103-108, 1999. 